\title{
The clinical risks of infection associated with endoscopy
}

\author{
Alistair E Cowen MD FRACP
}

\begin{abstract}
AE Cowen. The clinical risks of infection associated with endoscopy. Can J Gastroenterol 2001;15(5):321-331. The cleaning of flexible endoscopes is difficult and time consuming. Any method of attempted sterilization or high level disinfection will fail if prior cleaning has been defective. Inadequate reprocessing of endoscopes may result in patient to patient transmission of serious bacterial and viral diseases or infection with endemic hospital pathogens. Antibiotic prophylaxis is required to prevent septicemia and bacterial endocarditis in high risk patients undergoing specific endoscopic procedures. Prevention of serious endoscopy-associated clinical infections requires strict compliance with detailed reprocessing protocols by specially trained nursing staff.
\end{abstract}

Key Words: Antibiotics; Endoscopy; Infections

\section{Risques cliniques d'infection associés à l'en- doscopie}

RÉSUMÉ : Le nettoyage des endoscopes flexibles constitue une tâche longue et difficile. Aucune méthode de stérilisation ou de désinfection radicale ne sera efficace si le nettoyage préalable laisse lui-même à désirer. La retraitement inadéquat des endoscopes peut favoriser la transmission, entre patients, de maladies ou d'infections virales ou bactériennes graves compte tenu de la présence endémique d'agents pathogènes dans les hôpitaux. L'antibiothérapie prophylactique s'impose pour prévenir les septicémies et les endocardites bactériennes chez les patients à risque élevé, soumis à une intervention endoscopique. La prévention d'infections cliniques graves associées à l'endoscopie exige le respect rigoureux des protocoles détaillés de retraitement, et ce, par du personnel infirmier spécialement formé à cette fin.
$\mathrm{T}^{\mathrm{b}} \mathrm{cos}$ he self-regulation of traditional 'professions', particularly medicine, is frequently viewed with skepticism. There is an increasing demand for greater official regulation and accountability. A number of well publicized serial infections associated with medical procedures has undermined public confidence, particularly the transmission of human immunodeficiency virus (HIV) during minor surgery and the transmission of hepatitis $\mathrm{C}$ in association with anesthesia and endoscopic procedures (1-4).

The source of a variable but significant proportion of serious viral infections, including hepatitis $\mathrm{C}$ and acquired immune deficiency syndrome (AIDS), remains unexplained. The suggestion in the popular press that some of these infections may be medically acquired has further affected public confidence, despite the lack of evidence for such assertions. This has resulted in increasing consumer pressure for more stringent infection control measures in medical procedures including endoscopy. Inevitably, some of these demands are impractical. Such public pressure has recently led the American Society of Gastrointestinal
Endoscopy (ASGE) to issue public and professional information kits to its members.

Endoscopists and their professional societies have not, in the past, viewed endoscope and accessory reprocessing protocols as a high priority for either research or evaluation. This has had a number of unfortunate consequences. In the absence of user pressure, instrument manufacturers have not, until recently, considered the design and construction of endoscopes to allow more effective reprocessing to be a major research issue. Endoscopists and endoscopy societies have been slow to develop and test endoscope and accessory reprocessing protocols. Quality control systems during reprocessing have been largely absent, and patient infection detection systems absent or rudimentary.

The present review examines the risk of infection associated with endoscopic procedures, focusing particularly on the mechanism of infection, risk factors and the particular types of infection, together with the principles underlying safe and effective reprocessing protocols for endoscopes and their accessories.

This mini-review was prepared from a presentation made at the World Congress of Gastroenterology, Vienna, Austria, September 6 to 11, 1998

Department of Gastroenterology, Royal Brisbane Hospital, Brisbane, Queensland, Australia

Correspondence: Dr Alistair E Cowen, Royal Brisbane Hospital, Ballow Chambers, 121 Wickham Terrace, Brisbane, Queensland,

Australia 4000. Telephone+61-7-3832-3518, fax+07-3839-2018, e-mail acowen@medeserv.com.au

Received for publication July 15, 1999. Accepted July 19, 1999 


\section{RISKS OF INFECTION ASSOCIATED WITH ENDOSCOPIC PROCEDURES}

The ASGE estimates that the overall risk of patient to patient transmission of infection due to endoscopic procedures is one per 1.8 million examinations (5). This estimate is derived from user surveys and retrospective literature examination, both of which are well known to underestimate risks significantly. Nonetheless, this figure illustrates the rarity of serious patient to patient infection transfer. The risk of endoscopy-associated infections that are due to the contamination of instruments or accessory items with hospital environmental pathogens, or infections with the patient's own endogenous flora, is considerably higher.

Risk factors: The principal risk factors for endoscopy-associated infections are:

- the number and nature of organisms contaminating the endoscope and any accessory equipment used during the procedure;

- the nature of the endoscopic procedure being undertaken, particularly when it involves tissue penetration, disruption, ischemia or the introduction of devices into obstructed duct systems; and

- a variety of patient factors, including immune incompetence, integrity of endovascular surfaces and the presence of intrinsic infective foci adjacent to the area being examined.

In the push for 'sterile' endoscopes and accessories, the possibility that the infection may be endogenous is frequently overlooked. For example, in clinical infections associated with sclerotherapy, the organisms are usually the patient's endogenous flora rather than instrument or accessory contaminants.

Mechanisms of infection: The following distinct mechanisms are involved in endoscopy-transmitted infections.

- Infective material may be transferred in biological fluids from an infected patient to the endoscope or accessory equipment. If this material is not removed by cleaning and disinfection, it may be transmitted to patients subsequently examined with that instrument or accessory equipment.

- A variety of organisms contaminating the water supply (6-12) and organisms endemic in hospital environments may colonize endoscopes, washing machines (13-15), accessories, storage cabinets, water filters $(16,17)$, etc, and infect patients or produce pseudoinfections. Epidemics of pseudoinfections have occurred when atypical mycobacteria colonizing automatic disinfectors have contaminated bronchoscopes and biopsy specimens obtained during bronchoscopy (18-20), leading to an erroneous diagnosis of tissue infection with atypical mycobacteria. Because the drugs used to treat atypical mycobacterial infections may have major side effects, the clinical consequences can be serious.
The importance of recognizing these distinct mechanisms of infection lies in the fact that the measures needed to control infection risks are quite different. Prevention of patient to patient disease transmission via endoscopes and accessories is dependent on the efficacy of the reprocessing protocol used. Prevention of disease transmission by the second mechanism described above involves an additional range of measures, including a substantially bacteria-free water supply, and proper care, monitoring and bacterial surveillance of automatic processors, endoscopes and work environments.

\section{ENDOSCOPY-ASSOCIATED INFECTIONS}

Bacterial infections - Enteric Gram-negative pathogens: Endoscopy-associated clinical infections due to common vegetative enteric bacteria, including Salmonella species and Escherichia coli, should be nonexistent. Currently recommended reprocessing protocols should eliminate these bacteria or reduce the bacterial burden to a level that would not result in clinical infection (21), provided that the endoscope is used within a few hours, before significant proliferation of any remaining bacteria. Bacteriological surveillance of endoscopes that show a persistence of vegetative bacteria calls for a major review of reprocessing standards. Occasionally, internal structural damage to an endoscope may result in significant levels of vegetative bacteria persisting after adequate reprocessing.

Two important principles may be gleaned from reviewing the older literature reporting serial infections with vegetative bacteria (22-30). The usual response to the detection of serial infection transmission has been to prolong the chemical immersion time or to change the chemical disinfectant; in no case has this been successful. Where a clear breach in the cleaning protocol has been identified and corrected, serial transmission of infection has ceased immediately.

Mycobacterium tuberculosis: Mycobacterium tuberculosis is more resistant to chemical disinfectants than common vegetative pathogens $(31,32)$. There are a number of reports of transmission of $\mathrm{M}$ tuberculosis by flexible bronchoscopy, but none to date by gastrointestinal endoscopic procedures (3339 ). The pivotal role of cleaning and the relative importance of disinfection in reprocessing flexible endoscopes are dramatically illustrated by Nicholson et al (40), who demonstrated that mycobacteria remaining in inadequately cleaned flexible bronchoscopes persisted after a full $60 \mathrm{~min}$ disinfection in $2 \%$ glutaraldehyde, and that mycobacteria persisted in inadequately cleaned bronchoscopes after 10 sequential full disinfection cycles.

Further support for the critical role of cleaning comes from the transmission of Serratia marcescens by an inadequately cleaned flexible bronchoscope, despite a full $24 \mathrm{~h}$ ethylene oxide 'sterilization' process (41). This outbreak caused several deaths.

These results dramatically illustrate the folly of relying solely on longer disinfection soaking times to achieve endoscope 'sterility'. Unfortunately, with present endoscope design and construction, no attempts at disinfection or steriliza- 
tion will be successful if prior cleaning has been inadequate. The difficulty of detecting structural defects within the internal channels of flexible endoscopes, including fissuring, cracking, splitting, junction disruption and biofilm formation, makes it impossible to guarantee that endoscopes can always be sterilized.

Atypical mycobacteria: Atypical mycobacteria are common in tap water $(8,9,12)$, and the organisms frequently colonize automatic disinfectors $(13,42,43)$. Many atypical mycobacteria display adaptive chemical resistance (see 'Pseudomonas aeruginosa'), and decontamination of automatic processors may require the use of chemicals with which the organism is unfamiliar.

Atypical mycobacteria rarely cause clinical endoscopyassociated infection, except in immunocompromised patients. Pseudomonas aeruginosa: $P$ aeruginosa is an endemic hospital pathogen frequently present in tap water. Endoscopyassociated infections with $P$ aeruginosa have been uncommon in routine upper and lower endoscopic procedures. There have been occasional reports of septicemia in immunocompromised patients (44). Pseudomonas and related species (eg, Proteus species) have been the major organisms involved in serious clinical infections associated with endoscopic retrograde cholangiopancreatography (ERCP) and related therapeutic pancreaticobiliary endoscopic procedures $(45-57)$

The following principles have become apparent on reviewing the extensive literature of ERCP-associated infections with Pseudomonas species.

- Endoscopists have frequently been unaware of serial transmission of infection caused by their endoscopic procedures.

- Serial transmissions have almost universally been traced to inadequate cleaning $(58,59)$, contaminated water-feed systems $(60,61)$, contaminated automatic disinfectors (58), inadequately processed accessories and endoscope structural damage $(50,59)$.

- Bacterial monitoring of duodenoscopes and automatic processors has frequently been absent in institutions where disease transmission has occurred.

- Disease transmission due to errors and omissions in reprocessing protocols, which have been identified and documented in the literature, continue to occur years after the initial reports (60).

$P$ aeruginosa is another organism that appears to display adaptive chemical resistance. Kovacs et al (62) reported a resistant strain of $P$ aeruginosa recovered from tap water, which appeared to be responsible for three separate clinical episodes of ERCP-associated cholangitis over an 11-year period. Their finding emphasizes the critical importance of using sterile water for rinsing duodenoscopes, and in the water-feed system.

Helicobacter pylori: Transmission of $H$ pylori by contaminated biopsy forceps has been demonstrated by using restriction enzyme analysis of bacterial DNA (63). It is likely that the transmission of $\mathrm{H}$ pylori at endoscopy has been significantly underestimated. The high prevalence of the infection in the community being examined, together with the high level of symptoms in the population undergoing endoscopy that are identical or similar to acute Helicobacter infection, likely led to frequent failure to detect infection.

Viral infections: There has been surprisingly little evidence of transmission of serious viral diseases by endoscopy. Given the high infectivity of the hepatitis B virus (HBV), extensive studies showing an absence of disease transmission associated with endoscopy led to the assumption that it was highly unlikely that other viral diseases would be transmitted. Unfortunately, it appears this is not always the case. $\mathrm{HBV}$ : To date, there is only a single well-documented case of HBV transmission associated with endoscopy (64). A large number of studies, admittedly of varying quality, have followed patients endoscoped on the same list as HBVinfected patients, without finding evidence of transmission (65-72)

HIV: The possibility of HIV transmission at endoscopy is a serious concern and has been one of the major motivating forces in the recent improvement in cleaning and disinfection protocols. HIV is relatively sensitive to many chemical disinfectants $(73,74)$, and recommended reprocessing protocols have been shown to eliminate the virus from contamination scopes $(75,76)$.

There has been no proven case of endoscopic transmission. This should not lead to any degree of complacency. The extremely prolonged incubation time of clinical AIDS would make detection of isolated instances of HIV transmission at endoscopy extraordinarily difficult to detect.

Hepatitis C virus: The known physical characteristics of hepatitis $\mathrm{C}$ virus (HCV), its infectivity under ordinary clinical conditions and its known sensitivity to a variety of disinfectants led to the assumption that the risks of endoscopy-associated transmission would be similar to those of HBV; this has proved not to be true. The reason for the apparent discrepancy between HBV and $\mathrm{HCV}$ transmission at endoscopy is unknown. There is convincing evidence that transmission of $\mathrm{HCV}$ is associated with a number of endoscopic procedures. Tennenbaum et al (77) reported the transmission of HCV following endoscopic sphincterotomy. Transmission has also been associated with routine upper gastrointestinal endoscopy (2) and serial transmission demonstrated during colonoscopy (1). Epidemiological studies, including a national blood bank study (78) and individual hospital risk analysis (79), have suggested that endoscopy is a significant risk factor. To date, those clinical case reports and epidemiological evidence have all come from France. It is unlikely that this geographical restriction will continue. Only limited patient surveys have been done elsewhere in the world to confirm or refute the possibility of endoscopic transmission of HCV (80). In the majority of clinical cases reported from France there have been clear and obvious breaches of accepted reprocessing protocols. 
Other infections: A wide variety of organisms are known to be highly resistant to the chemical disinfectants usually employed in endoscope reprocessing. These organisms include Cryptosporidia species, Microsporidia species and Giardia species (81-84). In general, the possibility of transmission of these agents by endoscopy has not been studied.

An area of recent major concern has been spongiform encephalopathies. The spongiform encephalopathies, including Creutzfeldt-Jakob disease (CJD), are a family of aggressive neurological disorders characterized by the accumulation of an abnormal prion protein (85-97). The risk of transmission of the disease depends on the tissue level of abnormal prion protein. Tissues such as dura mater, brain and cornea contain high concentrations. Minimal to no prion proteins are present in blood, urine, feces, heart, bone marrow, nasal mucus, peripheral nerves, saliva, sputum, tears and blood $(85,89,92)$. Hemophiliacs who have had a massive lifetime exposure to blood and blood products have no increased incidence of CJD.

Prions are highly resistant to a variety of processes used to sterilize instruments, including steam, heat and chemical disinfectants $(91-94,96)$. This, together with the devastating nature of the disease, has led some to advocate disease control strategies that are grossly excessive.

In endoscopy, alternative diagnostic and therapeutic approaches should be considered in patients with known or suspected spongiform encephalopathies. When such procedures are totally unavoidable in CJD sufferers, patients may be referred to large centres where specific endoscopes are reserved. Endoscopic accessories used in patients with known or suspected CJD should be discarded. No change can be recommended in current reprocessing protocols for patients without increased risk of CJD.

\section{ANTIBIOTIC PROPHYLAXIS}

An important part of infection control in endoscopy is the appropriate and judicious use of antibiotic prophylaxis. Procedures with a significant risk of bacteremia in patients with compromised immune status, impaired endovascular integrity or indwelling foreign devices require antibiotic prophylaxis. Many studies have shown bacteremia to occur during endoscopic procedures (98-132). It should be noted, however, that bacteremia can occur with minor daily activities, even with vigorous teeth cleaning. It is, therefore, difficult to specify a qualitative or quantitative level of bacteremia that will become clinically significant. Recommendations for prophylactic antibiotics have varied widely (133-144). A pragmatic clinical approach is as follows.

- Routine upper gastrointestinal panendoscopy using thin instruments. No antibiotic prophylaxis is required, with the possible exception of severe mucositis in immunocompromised patients (eg, patients with bone marrow transplants or leukemia).

- Therapeutic upper gastrointestinal procedures involving tissue penetration or disruption, including esophageal dilation, injection sclerotherapy, mucosectomy and thermal destructive techniques. Antibiotics are required for patients with damaged or artificial valves, indwelling vascular devices, previous endocarditis and significant impairment of immune competence.

- Colonoscopy. Antibiotic prophylaxis is indicated in patients with damaged or artificial valves, indwelling vascular devices, previous endocarditis and significant impairment of immune competence, and in patients with acute peridiverticulitis.

- ERCP and therapeutic pancreaticobiliary endoscopy. Antibiotic prophylaxis commencing $12 \mathrm{~h}$ before the procedure in all patients with known duct obstruction or in those in whom therapeutic pancreaticobiliary procedures is to be undertaken (145-149).

The risk of endoscopy-related infections of orthopedic prosthetic devices, including joints and fixation devices, is extremely low (142). Prophylactic antibiotic cover is not recommended unless the device has been implanted within the previous three months or there has been previous prosthesis infection.

Recommended antibiotic regimens vary widely. A frequently used combination is an intravenous broad spectrum penicillin plus gentamicin, ampicillin or amoxycillin 1 to $2 \mathrm{~g}$, together with gentamicin 80 to $240 \mathrm{mg}$ given intravenously immediately before the procedure. Vancomycin $1 \mathrm{~g}$ given intravenously slowly before the commencement of the procedure is satisfactory for patients who are allergic to penicillin, have recently taken penicillin or are on long term penicillin therapy.

Antibiotic prophylaxis for ERCP is even more contentious. Randomized trials demonstrate that prophylactic antibiotics provide at least a modest benefit in patients at risk for cholangitis (145-149). The choice of antibiotics depends on local resistance patterns and may change in any specific area as bacterial resistance evolves. In general, older regimens of intravenous gentamicin, together with amoxycillin/clavulanate are being replaced with agents such as piperacillin and ciprofloxacin. The problem of developing resistance to piperacillin is frequently addressed by combining a beta-lactam inhibitor such as tazobactam.

\section{PRINCIPLES OF CLEANING AND DISINFECTION PROTOCOLS}

The details of appropriate cleaning and disinfection protocols are outside the scope of this review. Step by step details of effective decontamination protocols can be found in Infection Control in Endoscopy (150). Other important guidelines include Standard Practice for Cleaning and Disinfection of Flexible, Fiberoptic and Video Endoscopes Used in the Examination of Hollow Viscera published by the American Society for Testing and Materials (151) and Reprocessing of Flexible Gastrointestinal Endoscopes (152), a joint position statement by the American Gastroenterological Association, American Society of Gastrointestinal Endoscopy, American College of Gastroenterology and Society of Gastroenterology Nurses and Associates. The 
present review considers some of the important principles involved in reprocessing of endoscopes, including the effectiveness of recommended protocols and the place of automatic disinfectors.

Effectiveness of recommended protocols: A number of investigators have studied the effectiveness of cleaning and disinfection protocols in removing microbiological material from endoscopes. Hanson et al $(75,76)$ showed that recommended protocols remove all biological contamination from endoscopes used to examine patients with HIV and HBV infection. Their studies also confirmed that all microbiological activity was removed from endoscopes artificially contaminated with serum containing high titres of HBV and HIV. These findings were confirmed by the study of Deva et al (153). The following important findings came from this study.

- When followed meticulously, recommended reprocessing protocols removed microbiological contamination.

- Bacterial contamination was an accurate index of viral contamination.

- Even minor deviations from recommended cleaning protocols resulted in persistent microbiological contamination after disinfection.

Not all investigators have been able to confirm such satisfactory results. Colonoscopes artificially contaminated with Enterococcus faecalis had some remaining contamination after recommended reprocessing (154). Endoscopes artificially contaminated with $\mathrm{M}$ chelonae similarly failed to clear the infecting organism (155). A study applying 'in-use' tests found that not all bacterial contamination was removed by recommended protocols (156). In these and other studies $(21,22)$, the levels of bacterial contamination remaining were extremely low and were unlikely to cause significant clinical infection.

A study reporting remaining HIV RNA following recommended reprocessing protocols has raised concern (157). However, the significance of this finding is unclear because the viral nucleic acid was detected by polymerase chain reaction. A study using the duck hepatitis model showed that RNA detected by polymerase chain reaction after reprocessing was nucleic acid rather than infective viral particles (158). There has been no study demonstrating remaining infective HIV virus.

In general, the contamination remaining after recommended processing has been extremely small and is of doubtful clinical significance. These studies emphasize that currently recommended reprocessing protocols have a lower than desirable margin of safety, and that failure is likely if the cleaning steps are not followed in meticulous detail.

\section{THE ENDOSCOPY UNIT WATER SUPPLY}

Hospital tap water may be contaminated with a variety of bacteria, including Cryptosporidia species (159), Pseudomonas species and related species (6,61), atypical Mycobacteria species $(9,12)$ and Legionella species $(7)$. The quality of municipal water supplied to the hospital, the age of the hospital plumbing, the temperature of the hot water supply and the presence of plumbing alterations, particularly 'dead runs', all influence the likelihood of contamination.

The use of contaminated water during the cleaning phase is of little significance. However, when the instrument is rinsed after the disinfection cycle, contaminants introduced by the rinsing water may remain in damp areas of the endoscope and proliferate during storage. There is no easy solution to this problem. The use of sterile water for rinsing all endoscopes is extremely expensive. The simple solution of using filtered water has proved to be less than totally satisfactory in practice (14-17). Filtration is less expensive, but unless filters are meticulously maintained, contaminated filters may exacerbate rather than alleviate the problem, and it is clear that bacterial filters are less than $100 \%$ efficient. Although the issue of water quality is controversial, the following steps are recommended.

- The quality of the water in the endoscopy unit should be examined on a regular basis and, if significant contamination exists, filters installed.

- Filtered or sterile water must always be used for final and between patient rinsing of duodenoscopes and bronchoscopes. Alcohol rinsing and forced air drying at the end of lists are essential.

\section{ACCESSORY REPROCESSING}

Accessories that pierce tissue must be sterile. Contaminated endoscopic accessories have been responsible for infections with vegetative pathogens such as Salmonella species (27,30), M tuberculosis (33), H pylori $(63,160)$ and Pseudomonas species (58).

Accessories with fine tubing that are difficult to clean should be 'single use only', for example, injecting needles. Compound accessories, particularly those with spiral wire casing over a central core must be dismantled as far as possible and thoroughly cleaned ultrasonically before autoclaving. Although some authorities have advocated the use of 'single use only' biopsy forceps, there is substantial evidence to show that biopsy forceps can be fully sterilized by autoclaving (161). The space between the central wire and the spiral casing must be sterile. A more difficult problem is with a number of ERCP accessories and dilating balloons. The advisability of reusing devices such as sphincterotomes has been vigorously debated, with conflicting evidence presented (162-165).

\section{REUSE OF ITEMS LABELLED 'SINGLE USE ONLY'}

The reuse of items labelled 'single use only' is a complex and highly contentious area with ramifications in many branches of medicine (166-174). The major issues in reprocessing 'single use devices', as clearly stated in the compliance policy guide of the United States Food and Drug Association (175), are: 
- that the device can be adequately cleaned and sterilized;

- that the physical characteristics or quality of the device will not be adversely affected; and

- that the device will remain safe and effective for its intended use.

For the majority of endoscopic accessories, the major question is whether the device can be adequately cleaned and sterilized. Device failure during endoscopy is unlikely to have significant clinical consequences. Those who intend to reuse accessories labelled 'single use only', in the majority of Western countries, have a heavy legal liability to demonstrate sterility of the product.

Given the enormous financial implications of the 'single use only' policy, it would be unfortunate if reprocessing is abandoned. Device manufacturers should be encouraged to become involved in reprocessing their own products. They are usually in the best position to estimate the reprocessing requirements and limitations of their product. Research and development costs to validate reuse of accessories are substantial, and manufacturers require incentives such as preferred purchasing options.

\section{THE USE OF DIFFERING REPROCESSING PROTOCOLS ACCORDING TO THE PERCEIVED INFECTIVE STATUS OF A PATIENT}

A number of studies have shown that, when patients are known to have specific infections, particularly HIV, HBV and $\mathrm{HCV}$, the standard reprocessing protocol varies significantly (176-179). This will include the use of different disinfecting techniques such as substituting ethylene oxide sterilization for chemical disinfection or varying the chemical disinfectant, the concentration of the disinfectant or the time of immersion. Because the infective status of many patients is unknown or concealed, this policy is illogical and dangerous. Recommended protocols must allow endoscopes and accessories to be reprocessed safely, regardless of any patient infection.

\section{AUTOMATIC ENDOSCOPE DISINFECTORS}

Automatic endoscope disinfectors have been available in a variety of forms for over two decades. Acceptance in individual countries has varied widely, apparently depending on the economic parameters of the particular health system involved. A number of earlier automatic disinfectors were prone to contamination, and the design of some of these machines made contamination almost inevitable (59). Literature reports document that contaminated automatic endoscope processors have been associated with a large number of clinical infections and a number of deaths, and have been responsible for epidemics of pseudoinfection $(13,19,20,41-43,59,179-192)$.

The number of automatic disinfectors available is increasing rapidly. There has been major improvement in recent machines, and many of the previous design faults have been corrected. Claims that contamination problems have been eliminated are usually based on relatively slender in-house evaluation. Control studies in peer reviewed journals are frequently lacking. It is unlikely that machines will show contamination when new. Biofilm formation, valve failure, damaged seals and valves, filter failures and bacterial adaptive chemical resistance are all factors leading to colonization as machines age. Claims that any automatic disinfector can obviate the need for prior manual cleaning should be viewed with extreme skepticism. Such claims should not be accepted unless there is clear documented evidence of efficacy in peer reviewed journals.

Automatic disinfectors vary widely in design and chemical usage. The following principles should be used in considering the suitability of any automatic endoscope disinfector.

- Machines should have adequate fume containment systems.

- Machines should be plumbed into the water supply, and appropriate filtration systems, both pre-entry into the machine and within the machine itself, are necessary.

- It is critical that machines have flow alarms for all channels being processed. Machines should automatically monitor important functions, including temperature, time of disinfectant immersion, disinfection concentration, etc.

- Machines should have an effective automatic self-sterilization cycle at the end of operation. This aspect needs to be carefully investigated because manufacturers frequently use the term very loosely.

- Leak testing must be automatically carried out and the result recorded.

- Alcohol flushing and channel drying with filtered air are necessary cycle components.

It is critical that users of automatic endoscope disinfectors have a clear understanding of the principles and mechanics of the machine's operation, and understand the maintenance program required. It is also essential to understand bacteriological surveillance techniques and the protocols necessary to decontaminate colonized machines.

\section{PREVENTING ENDOSCOPY-ASSOCIATED INFECTIONS}

The principal cause of endoscopy-associated infections is failure to follow recommended protocols. A survey in France by Raymond et al (176) in 1990 showed that $73 \%$ of all units assessed had serious protocol deficiencies. Other studies in the United States and elsewhere have also demonstrated significant deficiencies $(177,178,193-196)$. It is generally believed that compliance with reprocessing protocols has improved dramatically in most Western countries in recent times. Hard evidence to support this assumption is frequently lacking, and anecdotal reports of isolated but serious deficiencies continue. 
Quality control systems are recognized as vital in most areas of industry. Endoscopy has been slow to accept the need for the development of quality control systems in reprocessing. Industrial experience suggests that processes that have clearly defined and automatically recordable progress points can successfully develop automated quality control systems. Throughout this review, it has been stressed that cleaning is by far the most critical part of recommended cleaning and disinfection protocols. Unfortunately, endoscope cleaning does not easily lend itself to automated quality control systems. Educational programs are, therefore, more likely to be more effective. Relevant societies in a number of countries are developing specific educational training programs for those involved in endoscope and accessory reprocessing. There appears to be little enthusiasm from health authorities to restrict endoscope reprocessing to suitably qualified personnel.

Disinfection parameters such as concentration, temperature and immersion time are much easier to monitor automatically. Better quality automatic endoscope processors already record and offer printouts of these parameters. The development and use of systems to record these progress points during manual reprocessing have been much slower. The extent to which quality control measures need to be documented and the records maintained is controversial.

The facility should be able to show that adequately trained staff members always use recommended cleaning and disinfection protocols. The instrument must be disinfected by either an automatic processor or a manual disinfection method where important parameters have been recorded. The endoscope and patients examined with the particular endoscope, both before and after the index case, should be readily identifiable. Accessories used during the procedure should either have been 'single use only' or reprocessed by a recognized method, including appropriate ultrasonic cleaning and autoclaving. When accessories labelled 'single use only' are reprocessed in-house, that accessory should be individually identifiable and have been reprocessed by a validated method.

Infections may be transmitted in ways other than via the endoscope, and its accessories and the anesthetic technique used must also be demonstrably safe and appropriate.

\section{MICROBIOLOGICAL SURVEILLANCE OF ENDOSCOPES}

One of the most difficult and controversial areas in infection control in endoscopy is the microbiological surveillance of endoscopes. Critics have claimed that it is time consuming, expensive, quantitatively inaccurate and inadequately validated. No detailed studies have used standard microbiological surveillance sampling techniques, removed the appropriate channels and other parts of the instrument, and subjected these to detailed bacteriological analysis. The absence of bacterial contamination using standard surveillance sampling techniques does not, therefore, prove that an endoscope is sterile (197). Microbiological monitoring of endoscopes should be viewed as an indirect marker of the adequacy and completeness of the cleaning and disinfection process, and as a measure of the structural integrity of the instrument.

Bacteriological surveillance has also been criticized because the major concerns of patient to patient disease transmission are of viral disorders such as HIV, HBV and HCV. Viral surveillance of endoscopes is clearly impractical for a number of reasons, but the work of Deva et al (153) confirmed that the presence or absence of bacterial contamination is an accurate reflection of viral contamination.

Controversy continues over the frequency of sampling, the organisms to test for and even the sampling technique. Cultures should be appropriate for common bacterial pathogens and mycobacteria. The most important organisms include vegetative bacteria, especially Salmonella and Pseudomonas species, $\mathrm{M}$ tuberculosis and atypical mycobacteria. Methods of sampling endoscopes and automatic disinfectors are described elsewhere (150). Testing frequency should reflect both the likelihood of contamination and the likelihood of serious clinical consequences from contaminated instruments. Automatic disinfectors, endoscopes processed in automatic disinfectors, and duodenoscopes and bronchoscopes reprocessed by any method should be cultured as frequently as second weekly. Standard endoscopes and colonoscopes can be examined less frequently, probably every two to four months.

Interpretation of culture results and the appropriate action should be undertaken in conjunction with a clinical microbiologist. Small numbers of environmental organisms may simply reflect inadequate sample processing. Any growth of Pseudomonas species or $\mathrm{M}$ tuberculosis would be cause for major concern, requiring immediate withdrawal of the endoscope and/or automatic disinfector from use until the problem is traced and rectified. Culture of enteric organisms from a single colonoscope may suggest an instrument defect or inadequate cleaning by a single person. Cultures of the same organism across a variety of instruments would indicate a serious unit reprocessing problem. Cultures of atypical Mycobacterium species likely reflect contamination of an automatic disinfector.

\section{PATIENT INFECTION DETECTION PROTOCOLS}

Few endoscopy units employ routine postprocedural surveillance programs to monitor the risk of endoscopy-associated infections. Such surveillance programs on a routine basis would be exorbitantly expensive, but it can be argued that such programs form part of any serious quality control policy. A cost effective approach may be to recommend that infection detection surveillance programs should exist at least intermittently for high risk procedures such as ERCP. The surveillance of low risk transmission procedures, such as endoscopy, may be better examined by wider risk analysis studies (eg, blood bank studies looking at the cause of acquisition of positivity for infections of concern, including HIV, HBV and HCV). 


\section{THE FUTURE}

Consumer pressure for more stringent infection control measures in endoscopy appears to have forced instrument manufacturers to take this aspect of endoscope and accessory design much more seriously. Accessories are now largely autoclavable or disposable, and there has been small but steady progress in the design of endoscopes. The aim must be to have endoscopes that are able to be fully sterilized. There are three main avenues to pursue this goal - the use of materials that can withstand conventional sterilizing processes such as steam heat, the use of novel processing machines and disinfectants, and the manufacture of endoscopes in which the parts subject to biological contamination are disposable. None of these approaches seems likely to be totally successful in the immediate future.

\section{ADDENDUM REGARDING CJD}

The transmission of mouse-adapted TSE from infected to healthy mice by blood and blood products (198-203) has caused widespread concern that CJD, particularly new variant CJD ( $v$-CJD), could be transmitted by prions remaining on surgical instruments and endoscopes despite reprocessing by currently recommended protocols. Such concerns are further heightened by the ability to detect and diagnose $\mathrm{v}$-CJD by tonsil biopsy in humans. The failure to demonstrate transmission of classical CJD by blood transfusion, blood products and heavily exposed instruments such as cardiac catheters (204-206), does not necessarily imply safety from transmission of $v$-CJD, which displays a number of properties differing from classical CJD. There is currently no clear answer to these concerns. The risks are unknown. If risk of transmission is established, then modification to endoscope reprocessing protocols is likely to be extremely difficult.

\section{REFERENCES}

1. Bronowicki JP, Venard V, Botte C, et al. Patient-to-patient transmission of hepatitis C virus during colonoscopy. N Engl J Med 1997;337:237-40.

2. Crenn P, Gigou M, Passeron J, et al. Patient to patient transmission of hepatitis $\mathrm{C}$ virus during gastroscopy on neuroteplanalgesia. Gastroenterology 1988;114:A1229. (Abst)

3. Surgeon transmits HIV to four patients. Austr Health Med Law Rep 1995:22-520,25,504

4. Goudin JL, Hot A, Dumont O, Bobichon R, Souquet JC. Systematic hepatitis $\mathrm{C}$ virus (HCV) screening in patients with previous digestive endoscopy. Gastroenterology 1995;114:A15. (Abst)

5. American Society for Gastrointestinal Endoscopy Ad Hoc Committee on Disinfection. Reprocessing of flexible gastrointestinal endoscopes. Gastrointest Endosc 1996;43:540-6.

6. Langer BKT, Daniels-Haardt I, Fischeder R, Boschek HJ. [Legionella, $P$. aeruginosa and atypical mycobacteria in home water supply systems at convalescent homes and hospitals of a large German city]. Forum Städte Hygiene 1990;451:286.

7. Lowry PN, Blankenship R, Gridley W, Tompkins L. A cluster of legionella sternal-wound infections due to postoperative topical exposure to contaminated tap water. N Engl J Med 1990;324:109-13.

8. Nye K, Chadha DK, Hodgkin P, Bradley C, Hancox J, Wise R. Mycobacterium chelonei isolation from broncho-alveola lavage fluid and its practical implications. J Hosp Infect 1990;16:257-61.

9. Grange JM, Yates MI. Infections caused by opportunistic mycobacteria - a review. JR Soc Med 1986;79:226-9.

10. MacKenzie WR, Hoxie NJ, Proctor ME, et al. A massive outbreak in Milwaukee of Cryptosporidium infection transmitted through the public water supply. N Engl J Med 1994;331:161-7.
11. Goldstein ST, Juranek DD, Ravenholt O, et al. Cryptosporidiosis: An outbreak associated with drinking water despite state-of-the-art water treatment. Ann Intern Med 1966;124:459-68.

12. Sniadack DH, Ostroff SM, Karlix MA, et al. A nosocomial pseudooutbreak of Mycobacterium xenopi due to a contaminated potable water supply: lessons in prevention. Infect Control Hosp Epidemiol 1993;14:636-41.

13. Maloney S, Welbel S, Daves B, et al. Mycobacterium abscessus pseudoinfection traced to an automated endoscope washer: utility of epidemiologic and laboratory investigation. J Infect Dis 1994;169:1166-9.

14. Cooke RP, Whymant-Morris A, Umasankar RS, Goddard SV. Bacteriafree water for automatic washer-disinfectors: an impossible dream? J Hosp Infect 1998;39:63-5.

15. Phillips G, McEwan H, Butler J. Quality of water in washer-disinfectors. J Hosp Infect 1995;31:152-4.

16. McKnight A, Cadwallader H, Thomas L. Is filtered rinse water for endoscopy sterile? Australian Infection Control Association 12th National Conference, Perth, May 18 to 19, 1998:95. (Poster 6)

17. Peadons J. Achieving filtered water with endocleaners. Australian Infection Control Association 12th National Conference, Perth, May 18 to $19,1998: 51$.

18. van Klingeren B, Pullen W. Glutaraldehyde resistant mycobacteria from endoscope washers. J Hosp Infect 1993;25:147. (Lett)

19. Fraser VJ, Jones M, Murray PR et al. Contamination of flexible fiberoptic bronchoscopes with Mycobacterium chelonae linked to an automated bronchoscope disinfection machine. Am Rev Respir Dis 1992;145:853.

20. Gubler JG, Salfinger M, von Graevenitz A. Pseudoepidemic of nontuberculosis mycobacteria due to a contaminated bronchoscope machine. Chest 1992;101:1245-9.

21. Chu N, McAlister D, Antonopios P. Natural bioburden levels detected on flexible gastrointestinal endoscopes after clinical use and manual cleaning. Gastrointest Endosc 1998;48:137-42.

22. Earnshaw JJ, Clark AW, Thoro BT. Outbreak of Pseudomonas aeruginosa following endoscopic retrograde cholangiopancreatography. J Hosp Infect 1985;6:95-7.

23. Cryan EM, Falkiner FR, Mulvihill TE, Keane CT, Keeling PW. Pseudomonas aeruginosa cross-infection following endoscopic retrograde cholangiopancreatography. J Hosp Infect 1984;5:371-6.

24. O'Connor BH, Bennett JR, Alexander JG, Sutton DR, Leighton I. Salmonellosis infection transmitted by fibreoptic endoscopies. Lancet 1982;ii:864-6.

25. Tufnell PG. Salmonella infections transmitted by a gastroscope. Can J Public Health 1976;67:141-2.

26. Chmel H, Armstrong D. Salmonella oslo - a focal outbreak in a hospital. Am J Med 1976;60:203-8.

27. Beecham HJ, Cohen ML, Parkin WE. Salmonella typhimurium. Transmission by fiberoptic upper gastrointestinal endoscopy. JAMA 1979;241:1013-5.

28. Dean AG. Transmission of Salmonella typhi by fiberoptic endoscopy. Lancet 1977;ii:134.

29. Schliessler KH, Rozendaal B, Taal C, Meawissen SGM. Outbreak of Salmonella agona infection after upper intestinal fiberoptic endoscopy. Lancet 1980;ii:1246.

30. Dwyer DM, Klein EG, Istre GR, Robinson MG, Neumann DA, McCoy GA. Salmonella newport infections transmitted by fiberoptic colonscopy. Gastrointest Endosc 1987;33:84-7.

31. Hanson PJV, Chadwick M, Nicholson G, et al. Mycobacterial resistance to disinfection in AIDS: whither infection control policies now? Thorax 1988;43:850.

32. Hanson PJV, Chadwick MV, Gaya H, Collins JV. A study of glutaraldehyde disinfection of fibreoptic bronchoscopes experimentally contaminated with Mycobacterium tuberculosis. J Hosp Infect 1992;22:13742 .

33. Wheeler PW, Lancaster D, Kaiser AB. Bronchopulmonary cross-colonisation and infection related to mycobacterial contamination of suction valves of bronchoscopes. J Infect Dis 1989; 159:954-8.

34. Leers WD. Disinfecting endoscopes: how not to transmit Mycobacterium tuberculosis by bronchoscopy. Can Med Assoc J 1980;123:275-83.

35. Bryce EA, Walker M, Bevan C, Smith JA. Contamination of bronchoscopes with Mycobacterium tuberculosis. Can J Infect Control 1993;8:35.

36. Reeves DS, Brown NM. Mycobacterial contamination of fibreoptic bronchoscopes. J Hosp Infect 1995;30:531-6.

37. Agerton T, Valway S, Gore B, et al. Transmission of a highly drugresistant strain (strain W1) of Mycobacterium tuberculosis. JAMA 1997;278:1073-7.

38. Michele TM, Cronin WA, Graham NMH, et al. Transmission of Mycobacterium tuberculosis by a fibreoptic bronchoscope. JAMA 
1997;278:1093-5

39. Wenzor RP, Edmond MB. Tuberculosis infection after bronchoscopy. JAMA 1997;278:111.

40. Nicholson G, Hudson RA, Chadwick MV, Gaya H. The efficacy of the disinfection of bronchoscopes contaminated in vitro with Mycobacterium tuberculosis and Mycobacterium avium-intracellulare in sputum: a comparison of Sactimed-I-Sinald and glutaraldehyde. J Hosp Infect 1995;29:257-64.

41. Webb SF, Vall-Spinosa A. Outbreak of Serratia marcescens associated with the flexible fiberbronchoscope. Chest 1975;68:703-8.

42. Reichert M. Automatic washers/disinfectors for flexible endoscopes. Infect Control Hosp Epidemiol 1991;12:497-9.

43. Griffiths PA, Babb JR, Bradley CR, Fraise AP. Glutaraldehyde-resistant Mycobacterium chelonae from endoscope washer disinfectors. J Appl Microbiol 1997;82:519-26.

44. Greene WH, Moody M, Hartley R, et al. Oesophagoscopy as a source of Pseudomonas aeruginosa sepsis in patients with acute leukemia: The need for sterilisation of endoscopes. Gastroenterology 1974;67:912-9.

45. Davis JL, Milligan FD, Cameron JL. Septic complications following endoscopic retrograde cholangiopancreatography. Surg Gynecol Obstet 1975;140:365-7.

46. Elson CO, Hattori K, Blackstone MO. Polymicrobial sepsis following endoscopic retrograde cholangiopancreatography. Gastroenterology 1975;69:507-10.

47. Thurnherr N, Bruhlmann WF, Krejs GI, Bianchi L, Faust H, Blum AL. Fulminant cholangitis and septicemia after endoscopic retrograde cholangiography (E.R.C.P) in two patients with obstructive jaundice. Dig Dis Sci 1976;21:477-81.

48. Schousboe M, Carter A, Sheppard PS. Endoscopic retrograde cholangiopancreatography: related nosocominal infections. NZ Med J 1980;92:275-7.

49. Noy MF, Harrison L, Holmes GKT, Cockel R. The significance of bacterial contamination of fibreoptic endoscopes. J Hosp Infect 1980;53-61.

50. Low DE, Micflikier AB, Kennedy JK, Stiver HG. Infectious complications of endoscopic retrograde cholangiopancreatography: a prospective assessment. Arch Intern Med 1980;140:1076-7.

51. Doherty DE, Falko JM, Lefkovitz N, Rogers J, Frornkes J. Pseudomonas aeruginosa sepis following retrograde cholangiopancreatography (E.R.C.P.). Dig Dis Sci 1982;27:169-70.

52. Allen JI, Allen MO, Olson MM, et al. Pseudomonas infection of the biliary system resulting from use of a contaminated endoscope. Gastroenterology 1987;92:759-63.

53. Bilbao MK, Dotter CT, Lee TG, Katon RM. Complications of endoscopic retrograde cholangiopancreatography (E.R.C.P.). Gastroenterology 1976:70:314-20.

54. Vennes JA, Jacobson JR, Silvis SE. Endoscopic cholangiography for biliary system diagnosis. Ann Intern Med 1974;80:61-4.

55. Classen DC, Jacobson JA, Burke JP, Jacobson JT, Evans RS. Serious pseudomonas infections associated with endoscopic retrograde cholangiopancreatography. Am J Med 1988;84:590-6.

56. Seigman-Igra Y, Isakov A, Inbar G, Cahaner J. Pseudomonas aeruginosa septicemia following endoscopic retrograde cholangiopancreatography with a contaminated endoscope. Scand J Infect Dis 1987:19:527-30.

57. Godiwala T, Andry M, Agrawal N, Ertan A. Consecutive Serratia marcescens infections following endoscopic retrograde cholangiopancreatography. Gastrointest Endosc 1988;34:345-7.

58. Struelens MJ, Rost F, Deplano A, et al. Pseudomonas aeruginosa and Enterobacteriaceae bacteremia after biliary endoscopy: an outbreak investigation using DNA macrorestriction analysis. Am J Med 1993;95:489-98.

59. Centers for Disease Control. Nosocomial infection and pseudoinfection from contaminated endoscopes and bronchoscopes - Wisconsin and Missouri. JAMA 1991;266:2197-8.

60. Bass DH, Oliver S, Bornman PC. Pseudomonas septicemia after endoscopic retrograde cholangiopancreatography: an unresolved problem. S Afr Med J 1990;77:509-11.

61. Alfa MJ, Sitter DL. In-hospital evaluation of contamination of duodenoscopes: a quantative assessment of the effect of drying. J Hosp Infect 1991;19:89-98.

62. Kovacs BJ, Aprecio RM, Kettering JD, Chen YK. Efficacy of various disinfectants in killing a resistant strain of Pseudomonas aeruginosa by comparing zones of inhibition: implications for endoscopic equipment reprocessing. Am J Gastroenterol 1998;93:2057-9.

63. Langenberg W, Rauws EA, Oudbier JH, Tytgat GN. Patient-to-patient transmission of Campylobacter pylori infection by fibreoptic gastroduodenoscopy and biopsy. J Infect Dis 1990;161:507-11.

64. Birnie GG, Quigley EM, Clements GB, Follet EAC, Watkinson G. Endoscopic transmission of hepatitis B virus. Gut 1983;24:171-4.

65. Ayoola EA. The risk of type B hepatitis infection in flexible endoscopy. Gastrointest Endosc 1981;2:60-2.
66. Bond WW, Moncada RE. Viral hepatitis B infection risk in flexible fiberoptic endoscopy. Gastrointest Endosc 1978;24:225-30.

67. Ferrari AR, Geocze S, Ferraz MLG, Silva AEB, Vilela ME. Lack of evidence of upper gastrointestinal endoscopy as a risk factor for transmission of Hepatitis B virus. Endoscopy 1991;23:353-4.

68. Galambos JT. Transmission of hepatitis B from providers to patients: How big is the risk? Hepatology 1986;2:320-5.

69. Hoofnagle JH, Blake J, Buskell-Bales Z, Seeff LB. Lack of transmission of type $\mathrm{B}$ hepatitis by fibreoptic upper endoscopy. J Clin Gastroenterol 1980;2:65-9

70. Lok ASF, Lai C-L, Hui W-M, et al. Absence of transmission of hepatitis B by fibreoptic upper gastrointestinal endoscopy. J Gastroenterol Hepatol $1987 ; 2: 175-80$

71. McClelland BDL, Burrell CJ, Tonkin RW, Heading RC. Hepatitis B: absence of transmission by gastrointestinal endoscopy. Br Med J $1978 ; 8: 23-4$

72. Moncada RE, Denes AE, Berquist K, Fields HA, Maynard JE. Inadvertent exposure of endoscopy patients to viral hepatitis B. Gastrointest Endosc $1978 ; 24: 231-2$

73. Hanson PJV, Gor D, Jeffries DJ, Collins JV. Chemical inactivation of HIV on surfaces. Br Med J 1989;298:862-4.

74. Resnick L, Veren K, Salahuddin SZ, Tondreau S, Markham PD. Stability and inactivation of HTLV III/LAV under clinical and laboratory environments. JAMA 1986;255:1887-91.

75. Hanson PJV, Gor D, Clarke JR, et al. Contamination of endoscopes used in AIDS patients. Lancet 1989;ii:86-8.

76. Hanson PJV, Gor D, Jeffries DJ, Collins JV. Elimination of high titre HIV from fibreoptic endoscopes. Gut 1990;31:657-9

77. Tennenbaum R, Colardelle $\mathrm{P}$, Chochon $\mathrm{M}$, et al. Hepatite $\mathrm{C}$ après cholangiographic retrograde. Gastroenterol Clin Biol 1993;17:763-4

78. Courouce AM and the French blood transfusion centers. Seroconversion to HCV in repeat blood donors. Proceedings of IX triennal International Symposium on Viral Hepatitis and Liver Disease. Rome, April 21 to 25, 1996.

79. Andrieu J, Barry S, Colardelle P, et al. Prevalence et facteurs de risque de l'infection par le virus de l'hepatite $\mathrm{C}$ dans une population hospitalisée en gastroenterologie. Role des biopsies per-endoscopiques. Gastroenterol Clin Biol 1995; 19:340-5

80. Kim YS, Ahn YO, Kim DW. A case-control study on the risk factors of hepatitis $\mathrm{C}$ virus infection among Koreans. J Korean Med Sci 1996:11:38-43

81. Angus KW, Sherwood D, Hutchison G, Campbell I. Evaluation of the effect of two aldehyde-based disinfectants on the infectivity of faecal cryptosporidia for mice. Res Vet Sci 1982;33:379-81.

82. Campbell I, Tzipori S, Hutchison G, Angus KW. Effect of disinfectants on survival of Cryptosporidium oocysts. Vet Rec 1982;111:414-5.

83. Barbee SL, Weber DJ, Sobsey MD, Rutala WA. Inactivation of Cryptosporidium parvum oocyst infectivity by disinfection and sterilization processes. Gastrointest Endosc 1999;49:605-11.

84. Finch GR, Black EK, Labatiuk CW, Gyurek L, Belosevic M. Comparison of Giardia lamblia and Giardia muris cyst inactivation by ozone. Appl Environ Microbiol 1993;59:3674-80.

85. Asher MA. Spongiform encephalopathies. In: Murray PR, ed. Manual of Clinical Microbiology, 6th edn. Washington: American Society for Microbiology, 1995:1121-30.

86. Bailes, BK. Creutzfeldt-Jakob disease - A fatal neurodegenerative transmissible disorder. AORN J 1990;52:976-84.

87. Will RG. Epidemiology of Creutzfeldt-Jakob disease. Br Med Bull 1993:49:960-70

88. Creutzfeldt-Jakob Disease and Other Human Transmissible Spongiform Encephalopathies. Guidelines on Patient Management and Infection Control. Canberra: National Health and Medical Research Council Australia, 1995.

89. Brown P. Environmental causes of human spongiform encephalopathy. In: Baker HF, Ridley RM, eds. Prion Diseases. Totowa: Himana Press, 1996:139-54

90. Committee on Health Care Issues, American Neurological Association. Precautions in handling tissues, fluids and other contaminated materials from patients with documented or suspected Cruetzfeldt-Jakob disease. Ann Neurol 1986;19:75-7.

91. Ernst DR, Race RE. Comparative analysis of scrapie agent inactivation methods. J Virol Methods 1993;41:193-201.

92. Geertsma RE, van Asten JA. Sterilization of prions. Cent Sterilization 1995;3:385-94.

93. Jarvis WR. Precautions for Creutzfeldt-Jakob disease. Infect Control 1982;3:238-9.

94. Steelman VM. Creutzfeldt-Jakob disease: Recommendations for Infection Control. Am J Infect Control 1994;22:312-8.

95. Taylor DM. Inactivation of the unconventional agents of scrapie, bovine spongiform encephalopathy and Creutzfeldt-Jakob disease. J Hosp Infect 1991;18(Suppl A):141-6. 
96. Favero MS, Bond WW. Chemical disinfection of medical and surgical materials. In: Block SS, ed. Disinfection, Sterilization and Preservation, 4th edn. Philadelphia: Lea \& Febeger, 1991:617-41.

97. Tyler KL. Prion diseases of the central nervous system (transmissible neurodegenerative diseases). In: Mandell GL, Bennett JE, Dolin R, eds. Principles and Practice of Infectious Diseases, 4th edn. New York: Churchill Livingston, 1995:881-7.

98. Reith AFR, Squier TL. Blood cultures of apparently healthy persons. J Infect Dis 1932;51:336-43.

99. Cobe HM. Transitory bacteremia. Oral Surg 1954;7:609-15.

100. Slade N. Bacteraemia and septicaemia after urological operations. Proc R Soc Med 1958;51:331-4.

101. Richards JH. Bacteremia following irritation of foci of infection. JAMA 1932;99:1496-7.

102. Shull HJ Jr, Greene BM, Allen SD, Dunn GD, Schenker S. Bacteremia with upper gastrointestinal endoscopy. Ann Intern Med 1975;83:212-4

103. Norfleet RG, Mitchell PD, Mulholland BS, Philo J. Does bacteremia follow upper gastrointestinal endoscopy? Am J Gastroenterol 1981;76:420-2.

104. O'Connor HJ, Hamilton I, Lincoln C, Maxwell S, Axon ATR. Bacteremia with upper gastrointestinal endoscopy - a reappraisal. Endoscopy 1983;15:21-3.

105. Mellow MH, Lewis RJ. Endoscopy-related bacteraemia. Arch Intern Med 1976;136:667-9.

106. Baltch AL, Buhac I, Agrawal A, O'Connor P, Bram M, Malatino E. Bacteremia after upper gastrointestinal endoscopy. Arch Intern Med 1977;137:594-7.

107. Liebermann TR. Bacteremia and fibreoptic endoscopy. Gastrointest Endosc 1976;23:36-7.

108. Kirk A, Graham-Brown R, Perinpanayagam RM, Smith RG, Barnardo DE. Bacteremia and upper gastrointestinal fibre-endoscopy. JR Soc Med 1979;72:409-11.

109. Nelson DB, Sanderson SJ, Azar MM. Bacteremia with oesophageal dilation. Gastrointest Endosc 1998;48:563-7.

110. Stray N, Midtvedt T, Valnes K, Rosseland V, Pytte R, Hoivik B. Endoscopy-related bacteremia. Scand J Gastroenterol 1978;13:345-7.

111. Stephenson PM, Dorrington L, Harris OD, Rao A. Bacteremia following oesophageal dilation and oesophago-gastroscopy. Aust NZ J Med $1977 ; 7: 32-5$.

112. Leitch DG, Collins JSA, Radhakrishnan S, O’Neill G, Dannatt J. Bacteraemia following endoscopy. Br J Clin Pract 1986;40:341-2.

113. Kaw M, Przepiorka D, Sekas G. Infectious complications of endoscopic procedures in bone marrow transplant recipients. Dig Dis Sci 1993;38:71-4.

114. Zuccaro G, Richter JE, Rice TW, et al. Viridans streptococcal bacteremia after oesophageal stricture dilation. Gastrointest Endosc 1998;48:568-73.

115. Yin TP, Ellis R, Dellipiani AW. The incidence of bacteremia after outpatient Hurst bougienage in the management of benign oesophageal strictures. Endoscopy 1983;15:289-90.

116. Snady H, Korsten MA, Waye JD. The relationship of bacteremia to the length of the injection needle in endoscopic variceal sclerotherapy. Gastrointest Endosc 1984;30:136. (Abst)

117. Cohen FL, Koerner RS, Taub SJ. Solitary brain abscess following endoscopic injection sclerosis of oesophageal varices. Gastrointest Endosc 1985;31:331-3.

118. Barthel JS, Sprouse RF, Dix JD, Sunderrajan EV. Fatal candida oesophageal abscess and sepsis complicating endoscopic variceal sclerosis. Gastrointest Endosc 1987;33:107-10.

119. Lai KH, Tsai YT, Lee SD. Spontaneous bacterial peritonitis after endoscopic variceal sclerotherapy. Gastrointest Endosc 1986;32:303.

120. Goenka MK, Thapa BR, Jethi SC, et al. Candidiasis complicating sclerotherapy-induced oesophageal ulcer presenting as recurrent hematemesis. Ind J Gastroenterol 1989;8:187-8.

121. Barnett JL, Elta G. Bacterial peritonitis following endoscopic variceal sclerotherapy. Gastrointest Endosc 1987;33:316-7.

122. Baskin G. Prosthetic endocarditis after endoscopic variceal sclerotherapy: a failure of antibiotic prophylaxis. Am J Gastroenterol 1989;84:311-2.

123. Ritchie MT, Lightdale CJ, Botet JE. Bilateral perinephric abscesses: a complication of endoscopic injection sclerotherapy. Am J Gastroenterol 1987:82:670-3.

124. Wong A, Rosenstein AH, Rutherford RE, James SP. Bacterial endocarditis following endoscopic variceal sclerotherapy. Clin Gastroenterol 1997;24:90-1.

125. Stiegmann GV, Goff JS, Michaletz-Onody P, et al. Endoscopic sclerotherapy as compared with endoscopic ligation for bleeding oesophageal varices. N Engl J Med 1992;326:1527-32.

126. Tseng C-C, Green RM, Burke SK, et al. Bacteremia after endoscopic band ligation of oesophageal varices. Gastrointest Endosc 1992;38:336-7.

127. Norfleet RG, Mulholland BS, Mitchell PD, Philo J, Walters EW. Does bacteremia follow colonoscopy? Gastroenterology 1976;70:20-1.
128. Dickman MD, Farrell R, Higgs RH, et al. Colonoscopy associated bacteremia. Surg Gynecol Obstet 1976;42:173-6.

129. Pelican G, Hentges D, Butt J, Haag T, Rolfe R, Hutcheson D. Bacteremia during colonoscopy. Gastrointest Endosc 1976;23:33-5.

130. Kiss A, Ferenci P, Graninger W, Pamperl H, Potzi R, Meryn S. Endotoxaemia following colonoscopy. Endoscopy 1983;15:24-6.

131. Hutani M, Puterbaugh M, Davis L, et al. Does endoscopic ultrasound result in bacteremia? A prospective evaluation. Gastrointest Endosc 1997;45:4.

132. Weber Ch, Fabricius H, Klein D, Dancygier H. Bacteremia following endoscopic ultrasonography of the upper gastrointestinal tract. Dept Int Med II \& Lab Med, Stadtische Kliniken Offenbach, Uni of Frankfurt, Offenbach/Main, Germany.

133. Schulman ST, Amren DP, Bisno AL, et al. Prevention of bacterial endocarditis: a statement for health professionals by the Committee on Rheumatic Fever and Infective Endocarditis of the Council of Cardiovascular Disease in the Young. Circulation 1984;70:1123A-7A.

134. Kaye D. Prophylaxis for infective endocarditis: An update. Ann Intern Med 1986;104:419-23.

135. The antibiotic prophylaxis of infective endocarditis: report of a working party of the British Society for Antimicrobial Chemotherapy. Lancet 1982;ii:1323-6.

136. Dajani AS, Bisno AL, Chung KL, et al. Prevention of bacterial endocarditis: Recommendations by the American Heart Association. JAMA 1990;264:2919-22.

137. Infection control during gastrointestinal endoscopy: guidelines for the clinical application. Gastrointest Endosc 1988;34:375-405.

138. Zuckerman GR, O'Brien J, Halsted R. Antibiotic prophylaxis in patients with infectious risk factors undergoing gastrointestinal endoscopic procedures. Gastrointest Endosc 1994;40:538-43.

139. Meyer GW. Antibiotic prophylaxis for gastrointestinal procedures: who needs it? Gastrointest Endosc 1994;40:645-6.

140. Antibiotic prophylaxis of infective endocarditis. Recommendations from the Endocarditis Working Party of the British Society for Antimicrobial Chemotherapy. Lancet 1990;335:88-9.

141. Williams CN. Antibiotic prophylaxis for gastrointestinal endoscopy. Can J Gastroenterol 1997;11:485-6.

142. Meyer GW, Artis AL. Antibiotic prophylaxis for orthopedic prostheses and GI procedures: Report of a survey. Am J Gastroenterol 1997;92:989-91.

143. Antibiotic prophylaxis for gastrointestinal endoscopy. American Society for Gastrointestinal Endoscopy. Gastrointest Endosc 1995;42:630-5.

144. Dajani AS, Taubert KA, Wilson W, et al. Prevention of bacterial endocarditis: Recommendations by the American Heart Association. Clin Infect Dis 1997;25:1448-58

145. Smith BC, Alqamish JR, Watson KJ, et al. Preventing endoscopic retrograde cholangiopancreatography related sepsis: a randomized controlled trial comparing two antibiotic regimes. J Gastroenterol Hepatol 1996;11:938-41.

146. Van den Hazel SJ, Speelman P, Dankert J, et al. Piperacillin to prevent cholangitis after endoscopic retrograde cholangiopancreatography: a randomized, controlled trial. Ann Intern Med 1996;125:442-7.

147. Byl B, Deviere J, Struelens MJ, et al. Antibiotic prophylaxis for infectious complications after therapeutic endoscopic retrograde cholangiopancreatography: a randomized, double-blind, placebo-controlled study. Clin Infect Dis 1995;20:1236-40.

148. Mehal WZ, Culshaw KD, Tillotson GS, Chapman RW. Antibiotic prophylaxis for ERCP; a randomized clinical trial comparing ciprofloxacin and cefuroxime in 200 patients at high risk of cholangitis. Eur J Gastroenterol Hepatol 1995;7:841-5.

149. Kullman E, Borch K, Lindstrom E, et al. Bacteremia following diagnostic and therapeutic ERCP. Gastrointest Endosc 1992;38:444-9.

150. Cowen AE, Rayner T, King B, Jones D. Infection Control in Endoscopy. Sydney: Gastroenterological Society of Australia, 1999.

151. American Society for Testing and Materials. Standard Practice for Cleaning and Disinfection for Flexible Fiberoptic and Video Endoscopes used in the Examination of the Hollow Viscera. West Conchohocken: American Society of Testing and Materials, 1994;F1518-94.

152. Reprocessing of Flexible Gastrointestinal Endoscopes, a joint position by the American Gastroenterological Association. Manchester: American Society for Gastrointestinal Endoscopy, 1996.

153. Deva AK, Vickery K, Zou J, et al. Detection of persistent vegetative bacteria and amplified viral nucleic acid from in-use testing of gastrointestinal endoscopes. J Hosp Infect 1998;39:149-57.

154. Cronmiller JR, Nelson DK, Salman G, et al. Antimicrobial efficacy of endoscopic disinfection procedures: a controlled, multifactorial investigation. Gastrointest Endosc 1999;50:152-8.

155. Kovacs BJ, Chen YK, Kettering JD, et al. High-level disinfection of flexible GI endoscopes: are current ASGE recommendations adequate? Gastrointest Endosc 1999;49:547-53. 
156. Bordas JM, Marcos-Maeso A, Perez MJ, Llach J, Terés. High level disinfection of duodenoscopes: assessment using "in use" tests. Gastrointest Endosc. (In press)

157. Vandervoort J, Tanasijevic M, Tham TCK, et al. HIV detection on endoscopes after high level disinfection. Gastrointest Endosc. (In press)

158. Deva AK, Vickery K, Zou J, West RH, Harris JP, Cossart YE. Establishment of an in use testing method for evaluating disinfection of surgical instruments using duck hepatitis B model. J Hosp Infect 1996;33:119-30.

159. MacKenzie WR, Hoxie NJ, Proctor ME, et al. A massive outbreak in Milwaukee of cryptosporidium infection transmitted through the public water supply. N Engl J Med 1994;331:161-7.

160. Graham DY, Alpert LC, Smith JL, Yoshimura HH. Iatrogenic Campylobacter pylori infection is a cause of epidemic achlorhydria. Am J Gastroenterol 1988;83:974-80.

161. Duforest D, Olesen S, Strudsholm M. A model for standardized reprocessing cycle for re-usable endoscopy accessories. 6th UEGW (United European Gastroenterology Week), Birmingham, October 18 to 23, 1997.

162. Kozarek RA, Raltz SL, Ball TJ, et al. Reuse of disposable sphincterotomes for diagnostic and therapeutic ERCP: a one year prospective study. Gastrointest Endosc 1999;49:39-42.

163. Kozarek RA, Raltz SL, Merriam LD, Sumida SE. Disposable versus reusable biopsy forceps: a prospective evaluation of costs. Gastrointest Endosc 1996;43:10-3.

164. Wilcox CM, Geels W, Baron T. How many times can you reuse a "single use" sphincterotome?: A prospective evaluation. Gastrointest Endosc $1998 ; 48: 58-60$

165. Lee RM, Kozarek RA, Raltz SL, Sumida SE. Risk of contamination of sterile biopsy forceps in disinfected endoscopes. Gastrointest Endosc 1998;47:377-81.

166. Re-Use of Single-Use Medical Devices: Making Informed Decisions, 1st edn. Plymouth Meeting: ECRI, 1996.

167. Canadian Healthcare Association. The Reuse of Single-Use Medical Devices. Guidelines for Healthcare Facilities. Ottawa: CHE Press, 1996.

168. Report of the NHMRC expert panel on re-use of medical devices labelled as single use. Canberra: Australian Government Publishing Service, 1997.

169. Brook CW. Reuse of single-use medical devices: NHMRC deliberations. Med J Aust 1996;164:537.

170. Collignon PJ, Graham E, Dreimanis DE. Reuse in sterile sites of single-use medical devices: how common is this in Australia? Med J Aust 1996;164:533-6.

171. Ball CK, Schafer EM, Thorne D. Reusing disposables: Same old story more characters added. Insight 1996;3:77-84.

172. Carr-Locke D, Conn M, Faigel D, et al. Disposable endoscopic accessories. Device reprocessing companies. Technology status evaluation. Gastroenterology 1988:48:717-22. $<$ http://www.asge.org/resources/manual/565.html>

173. Melzera Buess G. Reusable, re-posable and disposable instrumentation. Endosc Surg 1995; 3:127-8.

174. Rutala W, Barrett S, DiMarino AJ, Kozarek RA. Reprocessing of endoscopic devices: to use or reuse. Clinical Symposium, ASGE, Washington, May 13, 1997.

175. United States Food and Drug Administration. Reuse of medical disposable devices. Compliance Policy Guides. Section 300. 500 CPG 7124.16, 1987:58.

176. Raymond JM, Labadie JC, Fayon E, et al. Evaluation des procédures de décontamination utilisées dans les centres d'endoscopie digestive de Gironde. Gastroenterol Clin Biol 1990;14:134-9.

177. Reynolds CD, Rhinehart E, Dreyer P, Goldman DA. Variability in reprocessing policies and procedures for flexible fiberoptic endoscopes in Massachusetts hospitals. Am J Infect Control 1992:20:283-90.

178. Akamatsu T, Tabata K, Hironga M, Kawakami H, Uyeda M. Transmission of Helicobacter pylori infection via flexible fiberoptic endoscopy. Am J Infect Control 1996;24:343-5.

179. Kaezmarek RG, Moore RM Jr, McCrohan J, et al. Multi-state investigation of the actual disinfection/sterilisation of endoscopes in health care facilities. Am J Med 1992:92:256-61.

180. Struelens MJ, Rost F, Loriers M, et al. Septicemia after ERCP: outbreak linked to an automatic endoscope disinfecting machine. In: Proceedings of the 3rd International Conference on Nosocomial
Infections, Atlanta, Georgia 1990. Chicago: American Hospital Association, 1990. (Abst 731)

181. Lynch DAF, Porter L, Murphy L, Axon ATR. Evaluation of four commercial automatic washing machines. Endoscopy 1992;24:766-70.

182. Fraser VJ, Zuckerman G, Clouse RE, et al. A prospective randomized trial comparing manual and automated disinfection methods. Infect Control Hosp Epidemiol 1993;14:383-9.

183. Boks AL, Huurman AA, Leeuwen WB, et al. Disinfection of fiberscopes by thermochemical disinfection. Endoscopy 1991;23:19-24.

184. Muscarella LF. Advantages and limitations of automatic flexible endoscope reprocessors. Am J Infect Control 1996;24:304-9.

185. Bradley CR, Babb RJ. Endoscope decontamination: automated vs manual. J Hosp Infect 1995;30S:537-42.

186. Gubler JG, Salfinger M, von Graevenitz A. Pseudoepidemic of nontuberculous mycobacteria due to a contamination bronchoscope cleaning machine: Report of an outbreak and review of the literature. Chest 1992;101:1245-9.

187. Takigawa K, Fujita J, Negayama K, et al. Eradication of contaminating Mycobacterium chelonei from bronchofiberscopes and an automated bronchoscope disinfection machine. Respir Med 1995;89:423-7.

188. Reichert M. Automatic washers/disinfectors for flexible endoscopes. Infect Control Hosp Epidemiol 1991:12:497-9.

189. Cowen AE. Of Microbes, men and machines. Am J Gastroenterol 1998;93:2011-3.

190. Mitchell DH, Hicks LJ, Chiew R, Montanaro JC, Chen SC. Pseudoepidemic of Legionella pneumophila serogroup 6 associated with contaminated bronchoscopes. J Hosp Infect 1997;37:19-23.

191. Merighi A, Contato E, Scagliarini R, et al. Quality improvement in gastrointestinal endoscopy: microbiologic surveillance of disinfection. Gastrointest Endosc 1996;43:457-62.

192. Favero MS, Pugliese G. Infections transmitted by endoscopy: an international problem. Am J Infect Control 1996;24:343-5.

193. Gorse GJ, Roberta L, Messner RNC. Infection control practises in gastrointestinal endoscopy in the United States: A national survey. Infect Control Hosp Epidemiol 1991:12:289-96.

194. Rutala WA, Clontz EP, Weber DJ, Hoffman KK. Disinfection practices for endoscopes and other semi-critical items. Infect Control Hosp Epidemiol 1991;12:282-8.

195. Van Gossum A, Loriers M, Serruys E, Cremer M. Methods of disinfecting endoscopic material: results of an international survey. Endoscopy 1989;21:247-50.

196. Foss D, Monagan BA. A national survey of physicians and nurses attitudes towards endoscopic cleaning and the potential for cross infection. Gastroenterol Nurs 1992;15:59-65.

197. Muscarella LF. Instrument design and cross-infection. AORN J 1998;67:552-3

198. Brown P, Cervenakova L, McShane LM, Barber P, Rubenstein R, Drohan WN. Further studies of blood infectivity in an experimenta model of transmissible spongiform encephalopathy, with an explanation of why blood components do not transmit Creutzfeldt-Jakob disease in humans. Transfusion 1999;39:1169-78.

199. Turner M. The impact of new-variant Creutzfeldt-Jakob disease on blood transfusion practice. Br J Haematol 1999;106:842-50.

200. Murphy MF. New variant Creutzfeldt-Jakob disease (nvCJD): the risk of transmission by blood transfusion and the potential benefit of leukocyte-reduction of blood components. Transfus Med Rev 1999;13:75-83

201. Vamvakas EC. Risk of transmission of Creutzfeldt-Jakob disease by transfusion of blood, plasma, and plasma derivatives. J Clin Apheresis 1999;14:135-43.

202. Wilson K, Code C, Ricketts MN. Risk of acquiring Creutzfeldt-Jakob disease from blood transfusions: systematic review of case-control studies. BMJ 2000;321:17-9.

203. Collinge J. Variant Creutzfeldt-Jakob disease. Lancet 1999:354:317-23.

204. Fagih B, Eisenberg MJ. Reuse of angioplasty catheters and risk of Creutzfeldt-Jakob disease. Am Heart J 1999;137:1173-8.

205. Alter M. How is Creutzfeldt-Jakob disease acquired? Neuroepidemiology 2000;19:55-61.

206. Brown P. The risk of blood-borne Creutzfeldt-Jakob disease. Dev Biol Stand 2000;102:53-9. 


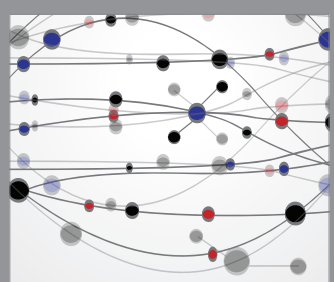

The Scientific World Journal
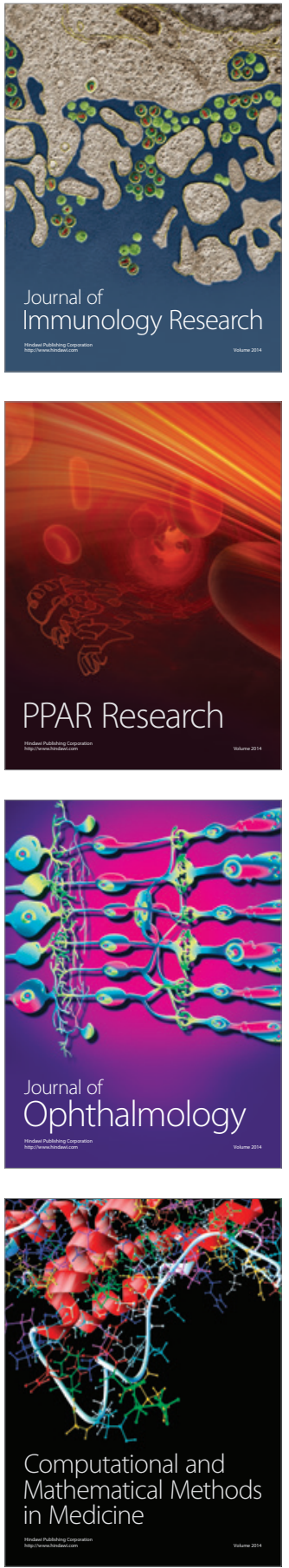

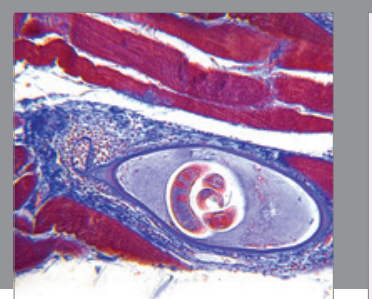

Gastroenterology Research and Practice

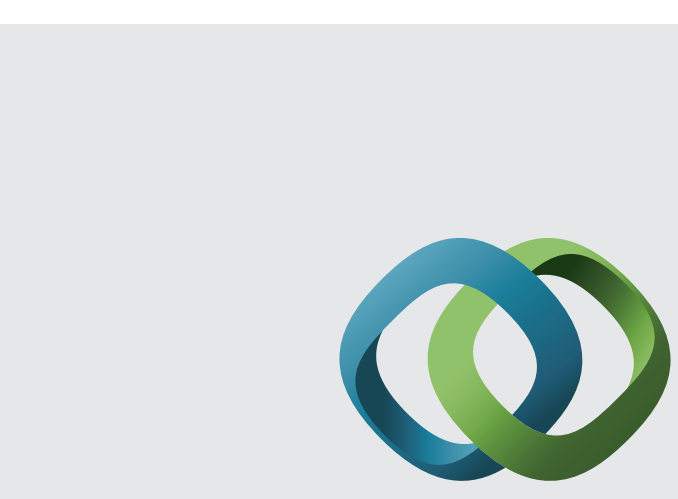

\section{Hindawi}

Submit your manuscripts at

http://www.hindawi.com
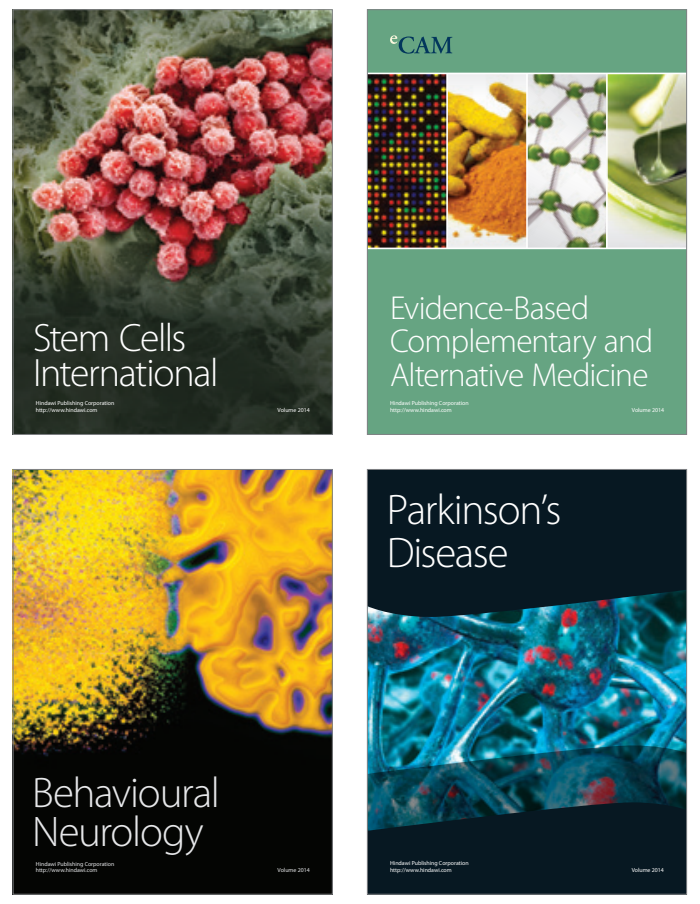
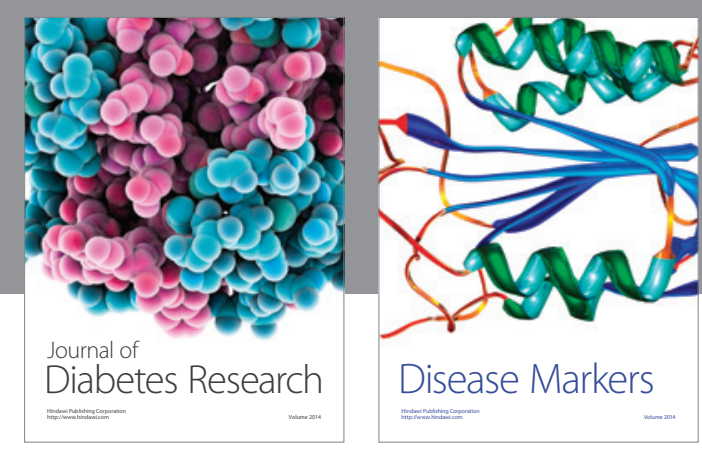

Disease Markers
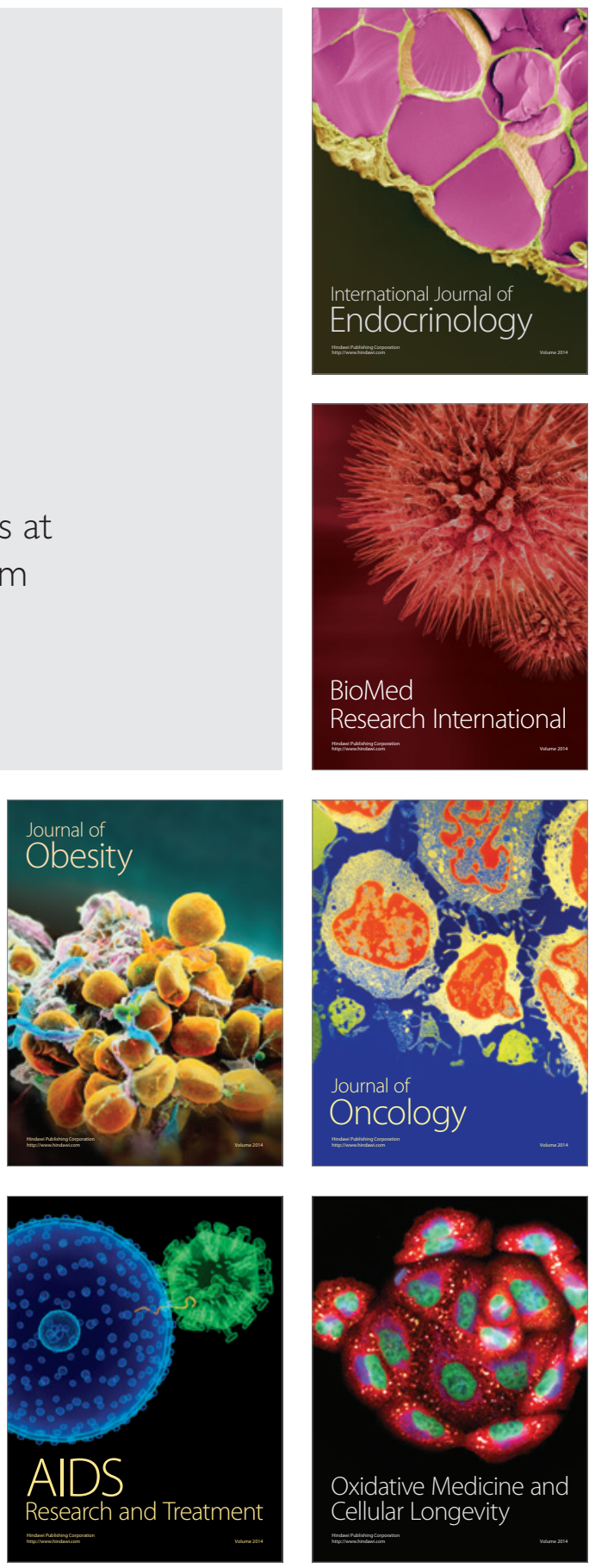